\title{
Social Level Parameters of Banjar Society in the Tradition of Jujuran Islamic Law Perspective
}

\author{
Muthoifin $^{1, *}$, Pristila Putri ${ }^{2}$ \\ ${ }^{1}$ Department of Islamic Studies Universitas Muhammadiyah Surakarta Indonesia. \\ ${ }^{2}$ Department of Islamic Economic Law Universitas Muhammadiyah Surakarta Indonesia. \\ *Corresponding author.Email:mut122@ums.ac.id
}

\begin{abstract}
This study aims to analyze the foundation used by the people of Tanah Bumbu Regency in determining jujuran, to understand the perspective of the Banjar people in Tanah Bumbu Regency about the philosophical values contained in jujuran customs, and to explain the correlation of Islamic views on dowry and jujuran in understanding. Banjar community in Tanah Bumbu Regency. This research is classified as field research. This research is analytical in nature, which is a continuation of descriptive research which aims not only to describe certain characteristics. But it also analyzes and explains why or how it happened, regardless of the approach used by anthropologists. The data criteria obtained are primary and secondary data. Data collection techniques used were in-depth interviews, observation, and literature study. The results of this study indicate that the dowry and jujuran in Tanah spice Regency are different, the number of jujuran can be influenced by several factors such as the social status of the parents, the beauty of the scientific material possessed by the prospective bride. But it still depends on the agreement of the two parties. Behind that, there is an inherent meaning, namely helping.
\end{abstract}

Keywords: Marriage, Jujuran, Banjar Customs, Islamic Law

\section{INTRODUCTION}

Marriage or what we often call marriage comes from the word nikah, which means to gather and unite, Marriage also unites two families by bonding through consent and qobul (akad nikah), which is something that requires a pair of humans to promise and bond with each other through words, according to Islamic law. [1]

The term nikah comes from Arabic, namely, (nikah) there are those who say marriage according to fiqh terms, the words of marriage and the words of Zawaj. Meanwhile, according to the Indonesian term is marriage. Today, it is often distinguished between marriage and marriage, but in principle, there are only differences in the root words. [2]

The marriage contract has several pillars that exist and are joined to the substance. The marriage contract also has conditions that are divided into several conditions, namely conditions for completion, legal requirements, conditions for implementation and mandatory requirements. Besides that, there are things that need to be considered such as dowry. In Islamic marriage law, Mahar is an obligation that must be paid by a groom to the bride. The payment of dowries is compulsory (Qur'an Surah An-Nisa '(4): 4 and 25). The money or things given as a dowry belong to the bride. In everyday speech, dowry is the same as dowry. In Indonesian indigenous peoples, the customs that apply in a region in our country, dowry is not the same as the dowry that is usually given by men to women. According to the customary law of marriage that applies in several regions in Indonesia, the dowry has its own function to restore magical equilibrium in the family of the woman because the woman who is married will move or leave her original family environment. [3]

Due to the values that live in indigenous peoples regarding the purpose of the marriage and regarding the honor of the family and relatives concerned in the community. Marriage in Banjar society is almost considered a sacred act, which everyone must live up to. A girl who has grown to maturity and according to the size of her village should be married and no one has proposed to her, is made to find her soul mate 
immediately. The Banjar tribe is one of the societies that differentiates between dowry and dowry on the grounds that they think that dowry is something that is given at the time of qabul consent. Meanwhile, the dowry is a gift given from the man to the woman, for example, a sum of money, cosmetics, a set of bedroom utensils and household utensils. [4]

\section{RESEARCH METHODS}

The approach that I use in this research is a case study approach. This case study focuses on analyzing cases that occur in the community using systematic methods. The type of research used in this research is qualitative research, more specifically by using field research. Field research is research whose data sources are mainly taken from the object of research (society or social community) directly in the research area. [5] The selection of informants is based on the number of informants in the field. This research must be based on direct vision from the subject. Determination of information is also not determined by the quantity, but the main thing is to describe it based on the findings. [6]

\section{RESULTS AND DISCUSSION}

Before discussing jujuran, the Banjar people in Tanah Bumbu Regency always start with the Badatang tradition. Badatang is a process to initiate or what we usually call an application. Usually if a man has gone to Badatang's side of the woman, that point of view is proof of the seriousness of a man. If the man is already in Badatang, then it is certain that the woman will discuss the issue of jujuran that the men will give to the women. Because this stage has entered a serious tap. During the Badatang tradition, questions about the number of jujuran asked by the woman will begin. Then from the woman's side will determine the number of jujuran which will then be agreed upon by both parties. This is where the bargaining process takes place. Even though bargaining occurs, the number of jujuran is still adjusted according to abilities and circumstances. [7]

Jujuran is a gift from the groom to the bride, jujuran can be in the form of money or things. This money or object can be used for wedding expenses. In addition to weddings, part of the jujuran money is used by the bride and groom to prepare for household life. In fact, many of the people use jujuran money as a dowry for the marriage contract so that this is what makes some people think that jujuran and dowry are the same thing. [8]

Local people think that jujuran is a tradition that must be done in a series of wedding ceremonies. This will be taboo if it is not carried out in a series of wedding ceremonies and will have the impact of gaining gossip among the community because it is considered disrespectful to cultural customs. Even so, jujuran culture has been known since the time of the prince. Before determining the number of jujuran, the point of view is the prospective bride and her words. Because if the house is in a tidy condition and the words of the prospective bride are good, it will reflect that their house will be neatly taken care of and the children will be well educated as well. [9]

Jujuran is synonymous with money, but there is no minimum or maximum limit, because a large amount of Jujuran is a mutual agreement between men and women. However, the size or size of a statement can be seen from several factors. [10]

First, the social status of the girl's parents means that if the girl's parent is a big official or entrepreneur, her Jujuran will be greater than that of girls from farmers' children or small traders. It will also be very different if the girl's parents are religious leaders, so they will be more honest than ordinary citizens. [11]

Second, the girl's education level. The number of jujuran can also be influenced by the level of education of the girl, because the banjar community believes that the mother is the first place of education for her children later. So that girls with a high level of education will get higher adjudication than girls with low education. Because the higher the girl's education, the more knowledge she has, the better it will be for her offspring. [12]

Third, the girl's beauty. Even though beauty is a relative thing, the Banjar people still differentiate Jujuran in terms of the girl's face. If the girl is more beautiful than other girls, the amount of jujuran this girl will be more than the face of an ordinary girl. This is an appreciation for the girl because she can maintain her beauty, so that many men want to become a wife. [13]

Fourth, because it was wanted from the girl's parents. This also often occurs in the jujuran tradition as the cost of marriage and the provision of life for the two brides. In an interview with Mesna Inderiani's mother, she is an orphan, she was approached by a man who wanted to propose to her, giving her a total of 20 million jujuran. However, Mesna's mother refused the amount, then asked to increase the number by 75 million. This is not because he wants to make it difficult for the man, but this money is used for the entire cost of the wedding ceremony later. Because after all this marriage is not a one-sided event, but an event of both parties. [14]

\section{CONCLUSION}

The people of Tanah Bumbu Regency, South Kalimantan understand that jujuran and dowry are different. A dowry is an obligation that must be paid by the man to the woman, while jujuran is a gift from the man to the woman as financial assistance in a wedding ceremony which is agreed by both parties. In terms of the number of jujuran influenced by the social strata owned 
by the woman. The strata here are not only from the royal family or royal descent, but can also be influenced by the family of the woman or even influenced by the woman herself, for example the woman already has a decent job, has a high level of education, has a beautiful face. Jujuran has now undergone a shift, which was originally used as a medium of mutual help and friendship. But now jujuran is used as a place for prestige regarding the number or amount of jujuran.

Jujuran as a social standard parameter in the Tanah Bumbu community is very common for the surrounding community. The amount of money for jujuran is always a benchmark for a girl's social status to be proposed. If a girl from an ordinary family but gets advice from a high prospective groom, it will raise the woman's social status. Actually the philosophical meaning contained in jujuran is the tradition of mutual help. Where both parties help each other in preparing for the wedding. Apart from that, jujuran also acts as a binding medium if the woman has received the jujuran money from the man, the woman is no longer allowed to accept applications from other men. The integration of jujuran with Islamic law is that jujuran with Islamic teachings has the same principle, namely the principle of mutual assistance and extending friendship.

Suggestion. For the community, it should still maintain a tradition that has been lived long ago as a national identity that contains local wisdom values and more importantly people must understand the relationship between jujuran and Islamic teachings. So that in the future every era development will be responded well without deviating from Islamic teachings and values. For all students of the Faculty of Islamic Religion, Muhammadiyah University of Surakarta, they should be more intense in conducting research in the field of entographics, to find out how the community maintains the principles of Islamic values in the traditional traditions of an area that are still preserved to this day. For further research, in order to present even more complex problems regarding entographic studies, so that they are more familiar with the society and traditions that apply in the area and correlate them with Islamic law.

\section{AUTHORS' CONTRIBUTIONS}

Muthoifin: First author, finishing, article editing, corresponding author, and doctor of Islamic studies. Pristila Putri: Second author, research data finder, and student of department of Islamic economic law Universitas Muhammadiyah Surakarta Indonesia.

\section{ACKNOWLEDGMENTS}

The authors would like to thank the rector UMS (Universitas Muhammadiyah Surakarta) and the chairman and staff of the LPPI (Lembaga Pengembangan
Publikasi Ilmiah) UMS for supporting the publication of this article.

\section{REFERENCES}

[1] T. Nopitalia and A. Efi, "Ba'usung Tradition in Wedding Ceremonies of Banjar Ethnic Group in Indragiri Hilir District," in Atlantis Press, 2020, vol. 458, no. Icssgt 2019, pp. 132-138, doi: 10.2991/assehr.k.200803.017.

[2] E. Suriansyah, "Perkawinan Adat Banjar Dalam Persfektif Struktural Mitos Levi-Strauss," elMashlahah J., vol. 9, no. 1, pp. 87-100, 2019.

[3] M. Munirah, "Memorizing the Qur'an as Banjarese Bride-Price (A Study of Living Quran and Hadith)," Ulumuna, vol. 21, no. 2, pp. 278-297, 2017, doi: 10.20414/ujis.v21i2.319.

[4] R. Akbari, "Jujuran Dalam Adat Banjar (Kajian Etnografis Hukum Islam Dalam Perkawinan Adat Banjar)," 2018.

[5] C. Williams, "Research Methods," J. Bus. Econ. Res., vol. 5, no. 3, pp. 65-72, 2007.

[6] Muthoifin, Nuha, and S. Shobron, "Education and Leadership in Indonesia: A Trilogy Concept in Islamic Perspective," Univers. J. Educ. Res., vol. 8, no. 9, pp. 4282-4286, 2020, doi: 10.13189/ujer.2020.080954.

[7] M. A. S. Nuruddaroini, "Adat Pernikahan Suku Banjar Dan Suku Bugis," Sos. Budaya, vol. 16, no. 1, p. 25, 2019, doi: 10.24014/sb.v16i1.6960.

[8] E. R. Nugroho and A. Wahid, "Perkawinan Tradisi Jujuran dalam Adat Bugis Perantau di Kutai Kartangera: Suatu Kajian Perbandingan dengan Hukum Islam," Wajah Huk., vol. 3, no. 2, p. 121, 2019, doi: 10.33087/wjh.v3i2.64.

[9] D. Aprilia, "Budaya jujuran dalam perkawinanadat banjar," no. 02810059, 2007.

[10] S. Shobron and A. Anshori, "Method for Developing Soft Skills Education for Students," Univers. J. Educ. Res., vol. 8, no. 7, pp. 3155-3159, 2020, doi: 10.13189/ujer.2020.080744.

[11] G. Muzainah, "Baantar Jujuran Dalam Perkawinan Adat Masyarakat Banjar," J. Al-Insyiroh J. Stud. Keislam., vol. 5, no. 2, pp. 10-33, 2019.

[12] S. Shobron and S. A. Rahman, "Humanist islam in indonesia ahmad syafii maarif perspective," Humanit. Soc. Sci. Rev., vol. 7, no. 6, pp. 780-786, 2019, [Online]. Available: https://giapjournals.com/index.php/hssr/article/vie w/hssr.2019.76118/2384. 
[13] N. Fadillah, “Tradisi 'Maantar Jujuran’ Dalam Perkawinan Adat Banjar Perspektif Konstruksi Sosial (Studi," 2017.
[14] Muthoifin, "Shariah Hotel and Mission Religion in Surakarta Indonesia," Humanit. Soc. Sci. Rev., vol. 7, no. 4, pp. 973-979, 2019, doi: 10.18510/hssr.2019.74133. 